UDC 378:011.3-057:331.45]:37.091.313

DOI: 10.31470/2518-7600-2019-6/2-151-170

\title{
USING THE PROJECT METHOD IN PROFESSIONAL TRAINING OF FUTURE LECTURERS IN PROFESSIONAL EDUCATION (OCCUPATIONAL SAFETY AND HEALTH) THROUGH THE COURSE ON PEDAGOGY OF HIGHER EDUCATION
}

\section{ОСОБЛИВОСТІ ВИКОРИСТАННЯ МЕТОДУ ПРОЕКТІВ У ПРОЦЕСІ ПРОФЕСІЙНОЇ ПІДГОТОВКИ МАЙБУТНІХ ВИКЛАДАЧІВ ПРОФЕСІЙНОЇ ОСВІТИ (ОХОРОНА ПРАЦІ) ПІД ЧАС ВИВЧЕННЯ ДИСЦИПЛІНИ «ПЕДАГОГІКА ВИЩОЇ ШКОЛИ»}

\section{Ольга Новак,}

кандидат педагогічних наук, старший викладач кафедри педагогіки

E-mail: novakolyia@gmail.com https://orcid.org/0000-00033187-1872

ID: D-1112-2019

ДВНЗ «Переяслав-

Хмельницький

державний педагогічний

університет

імені Григорія Сковороди», вул. Сухомлинського, 30, м. Переяслав-Хмельницький, Київська обл., Україна, 08401
Olha Novak,

$\mathrm{PhD}$ in Pedagogy,

Senior Lecturer of Pedagogy

E-mail:

novakolyia@gmail.com

https://orcid.org/0000-0003-

3187-1872

ID: D-1112-2019

Pereiaslav-Khmelnytskyi

Hryhorii Skovoroda State

Pedagogical University, 30,

Sukhomlynsky Str.,

Pereiaslav-Khmelnytskyi,

Kyivregion, Ukraine, 08401

\section{ABSTRACT}

The article analyzes the use of the project method in professional training of future lecturers in professional education (occupational safety and health) through the course on pedagogy of higher education.

It presents different approaches to clarifying the essence of the project method, which most scholars define as follows: a 
method, a type of learning, an educational technology. Based on different views of scholars on the concept of the project method, we consider it as a set of learning and cognitive techniques, which allow students to acquire new knowledge, skills and abilities during independent learning focused on creative self-realization of the individual in the education process and aimed at increasing their professional training in higher education institutions.

The article specifies the essence, content and structure of the project method. It is proved the use of the project method in professional training of Master students in comparison with traditional methods has a number of advantages: the learning process is adjusted to practice; students have the opportunity to engage in independent professional activity; students are faced with the need to find and make optimal decisions; students have the opportunity to creatively acquire the necessary information.

The article it is the systemic use of the project method in professional training of students, namely in the context of the course on pedagogy of higher education, contributes to developing professional skills and thinking, creative and research skills, problem-solving skills, to develop their core competences (cognitive, communicative, research ones, project), innovation skills and widening social mindset of future lecturers in professional education (015 occupational safety and health).

Keywords: higher education, project method, competency, professional training, future lecturers in professional education (occupational safety and health), the course on pedagogy of higher education, the education process.

Problem statement. Such aspects as globalization and democratization processes, a growing role of knowledge and practical experience for its development and Ukraine's integration into European Higher Education Area greatly increase the requirements for lecturers' qualifications, competencies and competitiveness in the global labour market, their ability to adapt to modern fast-changing socioeconomic conditions and scientific and technological advances, innovation skills, creative and system thinking. This, in turn, causes the need for new educational approaches to professional training of future lecturers (occupational 
safety and health) since it involves acquiring not only theoretical knowledge and specialist skills but also their professional growth as high-qualified specialists.

If future lecturers in professional education (occupational safety and health) intend to be efficient, they should be able to study and develop educational and methodical programmes, plan the educational process, model and implement different projects, discover novel ways to solve professional tasks. Thus, they should have relevant analytical and project skills and be creators rather than mere performers. It is precisely educational projects, which allow the individual to plan their own development and enhance their creative thinking and inventive skills, professionalism and work capacity, socially important value orientations and ability to predict the consequences of probable changes.

Therefore, it is rather important to provide master students in professional education (015 occupational safety and health) with the relevant knowledge of the project method since the level of their professional competency and performance mainly depends on it.

Analysis of recent researches and publications. The content analysis of scientific sources proves that the problem of different specialists' professional training is studied in different contexts: components of professional training and modern requirements for professional training of students (Бондар, 1996; Ничкало, 2007 et al.). Different aspects of the project method were studied by foreign (Гузеев, 2001; Дьюи, 1992; Килпатрик, 1925; Пилюгина, 2002; Полат, 2003; Селевко, 2006; Howell, 2003 et al.) and Ukrainian (Гуревич, 2012; Срмаков, 2003; Зазуліна, 2006; Колодницька, 2009; Ліготський, 1995; Логвин, 2004; Пєхота, 2002; Ящук, 2004 et al.) scholars.

Unknown aspects of research problem. One should further analyze the use of the project method in professional training of future lecturers in professional education (occupational safety and health) in the context of the course on pedagogy of higher education.

The research aims to analyze scientific and reference literature to specify the use of the project method in professional training of future lecturers in professional education (occupational safety and health) in the context of the course on pedagogy of higher education. 
The research objectives are the following: to analyze the project method; to clarify its essence, content and structure; to determine the conditions for its effective use in professional training of future lecturers in professional education (occupational safety and health) in the context of the course on pedagogy of higher education.

Results. Due to the transformations taking place in Ukraine nowadays, higher education faces new challenges since it plays a leading role in increasing the country's scientific and intellectual potential. The requirements for professional training of future lecturers in professional education (015 occupational safety and health) are growing and becoming more complex in accordance with the needs of society and scientific and technological progress.

Therefore, the main objective of professional education is to train a highly skilled specialist of international standards, who is competitive in the labour market, competent, responsible, mobile, able to quickly adapt to the emerging challenges, creatively perform professional activities, ready for effective professional work at the level of world standards. It must be noted that project-based activities are ideally suited for this need since they promote active involvement and implementation of life plans of higher education graduates. After all, the present conditions of active search and research foster advanced and creative development of individuals, who design and organize their own lives and expediently transform the world around. The ability to use this method is an indicator of teachers' high professional qualifications and progressiveness of their teaching methods. Therefore, the systematic use of the project method in the education process allows future lecturers in professional education ( 015 occupational safety and health) to independently acquire new knowledge and apply it in practice to solve life and professional problems in professional activities.

The project method emerged in the USA in the 1920s. It was originally called «the problem-project method» and developed within the humanistic direction in philosophy and education and pedagogical views and experimental work of J. Dewey and his follower W. Kilpatrick, who developed the «project-based learning» (Пехота, 2004). 
It must be noted that the project method has gained wide popularity in pedagogical theory and practice all over the world due to a rational combination of theoretical knowledge and its practical application to solve specific problems.

The term project (from Latin: «Projectum») means «to throw forward» (Ліготський, 1995). It is often associated with the concept of problem. The project as a problem implies «a process of creation, during which the individual ceases to be a mere owner of ideas and sacrifices his/her something private to be able to discover something else, absorb it, reveal it in his/her work. The solving of some problem involves, on the one hand, using a set of diverse methods, learning techniques, and, on the other hand, the need to integrate knowledge and ability to apply it in various fields of science and technology. It is such an interpretation of the project which offers wide opportunities for its use in the education process» (Полат, 2003: 9).

The content analysis of scientific literature shows that many definitions of the project method indicate a lack of a single and clear paradigm of its use among researchers. The project method is considered as a method: a personality-oriented method of learning based on students' independent work, which includes researching some problem and formulating its practical result (Пилюгина, 2002: 196); as a type of learning: a collaborative approach, which allows students to acquire knowledge and apply it to solve realistic problems during extensive research (Howell, 2003: 13); as an activity: a way of organizing students' cognitive activities to solve some problems associated with designing, creating and producing real objects (a product of labour) (Ящук, 2004: 10); as an educational technology: a pedagogical technology, which makes it possible to find a solution to the problem and make some changes in the environment (natural and artificial); obtaining of a concrete (practical) result and its public presentation (Селевко, 2006: 228).

Nowadays, the project method or project technology (from Greek: «techne» - art, craft, skills and «logos» - science) is considered as «a tool, which creates unique prerequisites for developing core competences (communicative, project, cognitive, research ones), fostering independence in comprehending something new and stimulating students' natural curiosity and 
creative potential» (Срмаков, 2003: 16). It occupies a special place as a means of adjusting the individual to real life and involving him/her in solving specific problems.

Given its different interpretations, the concept of the project method, we consider it as a set of learning and cognitive techniques, which allow students to acquire new knowledge, skills and abilities during independent learning focused on creative self-realization of the individual in the education process and aimed at increasing their professional training in higher education institutions.

The essence of the project method is rooted in fostering students' interest in certain problems. This, in turn, requires that they have relevant knowledge and are able to apply it when solving problems within some project.

The main objectives of the project method are: to learn how to achieve the set goals independently; to learn how to predict some minor problems needed to be addressed; to learn how to work with information and find the sources from which it can be taken; to learn how to conduct research and transfer and present the acquired knowledge and experience; to develop teamwork skills and business communication skills within a group.

The project method has the following structure: the name; a form of presentation; the main idea; goals and objectives; completion deadline; stages of work; conditions for student participation (organizational or technical ones); types of their activities; forms of interaction between participants; methods of diagnosing and evaluating intermediate and final results; possibility of its continuation after implementation (Гуревич, 2012).

The project method involves implementing a system of didactic tools (content, stages, methods, etc.) and modelling problem situations. Therefore, students should be able to discover effective ways to solve the defined problems, analyze the obtained results and present them.

The main stages of project-based activities are the following: a preliminary project (outlining the problem and justifying practical value of its results); project planning (determining goals and objectives; defining the scale and stages of work, means and methods to achieve the goals); analysis stage (predicting probable difficulties and completion deadline; formulating the hypothesis and 
ideas of project implementation; generalization stage (designing the project model and its structure); results presentation (presenting the project using visual aids (tables, diagrams, figures)). The stages of educational project-based activities include diagnostics of a situation, project problematization and its conceptualization.

The value of the project method consists in the fact that it develops students' cognitive and creative skills, their ability to independently construct their knowledge and fosters a conscious attitude towards professional activities. It aims to achieve didactic goals through a detailed solving of the defined problem, which should have relevant practical results and be formulated properly. These goals can be achieved if students are able to think independently, outline and solve problems, integrate knowledge of different subjects, establish causal relationships, predict the consequences of implementing various options.

In terms of the project typology, one defines the following categories: by a prevailing activity: research, search, creative, roleplaying, applied, theoretical; by subject and content: mono projects (in the context of one branch of knowledge), interdisciplinary projects; by coordination: direct (rigid or flexible), hidden; by interaction: participation of students from one academic group, several students, students of the whole department (or faculty); by the number of participants; by duration of implementation (Гуревич, 2012).

Research projects are conducted according to the logic and structure of scientific research and are used in the process of researching. It involves shaping the ability to determine research object, subject, goals, objectives and formulate hypotheses and select the most effective research methods. This type of project is designed to solve non-standard tasks and contributes to developing critical thinking and creative skills. Creative projects are characterized by a specific formulation of results. Gaming and roleplaying projects include educational games, during which students perform certain roles in accordance with the topic and content of the project. Informational projects allow students to develop the ability to collect, systematize, analyze and generalize educational and scientific material, using various methods for obtaining and processing information. Such projects are effectively implemented 
during educational business games in practical classes. Practiceoriented projects aim to create reference materials, various programmes, optional classes, scripts of educational and practical events, some material on the history of the origin of certain concepts and terms used in various fields of science. Such projects can be used as part of coursework and master dissertations.

One of the main prerequisites for successful project implementation is psychological support of successful communication between project participants.

When selecting a topic for a project, it is necessary to involve students, namely future project participants, since it ensures a high motivational component of this activity and its social context.

The criteria for evaluating project-based activities are: awareness in determining a problem, selecting a topic for a project, its practical orientation and value; rationale of the proposed solutions, approaches and conclusions; implementation of the accepted project stages, independence, completeness; the level of creativity and originality of project presentation; documentation quality; report quality: completeness of presentation, argumentation and persuasiveness; volume and depth of knowledge on the topic, erudition; answers to questions: completeness, argumentation; business and volitional skills: responsibility, friendliness, communication (Гуревич, 2012).

Thus, the project method is based on the productive activity of each participant and involves joint creative activities; the project method can be described as "learning through actions" since students are involved in an active cognitive process. Indeed, they independently formulate the problem, collect the necessary information, discover and compare options for solving problems, make conclusions, analyze their own activities and, most importantly, gain new educational and life experience.

The use of the project method in professional training of Master students in comparison with traditional methods has a number of advantages: the learning process is adjusted to practice; students have the opportunity to engage in independent professional activity; students are faced with the need to find and make optimal decisions; students have the opportunity to creatively acquire the necessary information. 
Therefore, the most valuable result of project-based activities is students' acquisition of project and communication skills; the main goals of the project method mainly in professional training of future lecturers in professional education (015 occupational safety and health) are the following: to involve students in active professional activities, real relationships and actions, which can help them to comprehend social and personal significance of this activity, to correlate it with the obtained results, to evaluate their own inclinations and capabilities to perform this activity; to stimulate students' interest in solving problems independently, gaining knowledge from various fields and sources, which can be useful for life and professional activities until they have obtained their own professional experience; to create appropriate conditions for students to develop their critical thinking, intellectual and creative skills; to shape core competences (communicative, project, cognitive, research ones).

The current research considers the use of the project method in professional training of future lecturers in professional education (occupational safety and health) through the course on pedagogy of higher education.

Thus, pedagogy of higher education is one of pedagogical branches and science about upbringing, learning and education of youth and adults. It deals with the patterns of student education, as well as their scientific and professional training as specialists in accordance with state requirements.

It aims to provide master students with the holistic and logical knowledge about pedagogical principles of professional training in higher education institutions; to prepare future specialists capable of self-organized learning and self-development, who have the basic pedagogical knowledge and are able to successfully apply it in everyday and professional practice when solving pedagogical situations related to education and development.

The objectives of the course are the following: ensuring practical training of future specialists on such issues as deepening, expansion, integration of knowledge about pedagogy of higher education, pedagogical mastery, modern educational technologies; fostering students' understanding of various forms of the education process organization in higher education institutions; cultivating 
personal qualities of future pedagogue, lecturer, tutor in master students; increasing their interest in self-organized learning, selfeducation and self-improvement.

Upon completion of the course, future lecturers in professional education (015 occupational safety and health) are expected to have the following knowledge, abilities and skills: the main categories of higher education pedagogy; methods of pedagogical research in higher education; comprehension of the higher education system in Ukraine and directions for its development; the essence and characteristics of components of the education process; the types, directions, methods, forms of education of the student youth; the organizational forms of learning; modern educational technologies; understanding of age characteristics of students' professional and personal development; functions of managing higher education institutions; the concept of pedagogical mastery; the ability to analyze and explain psychological and pedagogical phenomena and processes in higher education institutions; the ability to conduct psychological and pedagogical researches; the ability to take into account age characteristics of students when designing components of the education processes; the ability to develop and conduct classes using modern educational technologies; the ability to use the means of pedagogical communication, interaction and influence.

The main aim of the project method in professional training of future lecturers in professional education (015 occupational safety and health) in the context of the course on pedagogy of higher education consists in the fact that the project work and project technology are the forms of educational activities, which allow students to engage in productive independent work within the course on pedagogy of higher education in all aspects, integrating practical, developmental and educational goals of master's degree studies. The project technology is oriented towards a specific, clearly defined educational product of project-based activities. It must be noted that the project method is based on the idea of interaction and cooperation between students during the education process and creates the appropriate conditions for developing their socially active personal qualities so that they are able to interact with peers and be responsible for the results of personal and 
collective cognitive activities. This, in turn, creates conditions for personal socialization and increases the individual's business activity and develops his/her professional competency.

For one, future lecturers in professional education (015 occupational safety and health) familiarize themselves with theoretical and practical aspects of pedagogical technologies in higher education during the lecture on "Using Modern Educational Technologies in Higher Education”. It is aimed at developing students' knowledge of modern pedagogical technologies in higher education, motivating them to enhance their methodological and psychological and pedagogical competences, innovation and pedagogical activities, increasing their cognitive and technological readiness to design pedagogical projects and implement them in practice. The lecture covers the following issues: the essence and content of modern pedagogical technologies; the characteristics of incorporating pedagogical technologies in practice of lecturers in professional education (015 occupational safety and health); modern technologies of educational work organization in higher education; the essence of innovative pedagogical activity in higher education; the essence of the project method; the stages of project creation and implementation.

The main objectives of the course on pedagogy of higher education are: to familiarize future specialists with the main theoretical principles of modern pedagogy of higher education; to form their scientific views on the patterns of the education process, as well as to show them the model of the interaction between teachers and students within and beyond the context of higher education; to develop their holistic views on pedagogical activity and awareness of themselves as the subjects of this activity; to shape their teaching position, value orientations of understanding of the goals and objectives of pedagogical activity; to teach them how to use their own personal potential to solve different pedagogical tasks; to motivate them to strive for professional and pedagogical selfimprovement; to develop their pedagogical thinking and analytical understanding of pedagogical reality, reflection on their own pedagogical activity.

Given that lectures mostly involve studying theoretical material and shaping knowledge, the functions of goal-setting and 
activization of skills and abilities, which form the content of professional competency of future lecturers in professional education (015 occupational safety and health), were incorporated into practical classes, which include implementing individual creative projects on the problems of higher education pedagogy.

Practical classes include studying and discussing theoretical issues, developing and presenting individual, group, collective projects, creative tasks. Therefore, practical classes allow students to activate practical skills in the methodology of project preparation, which should be considered as the main form of organizing independent work of Master students. Below is an example of the project titled «My Professional Future» prepared by Dmytro Z., a student of Op-11 pm group.

Goals: the educational aspect: to enhance striving for new knowledge; to develop the ability to construct knowledge; to study the most important methods of scientific knowledge; to develop the abilities to single out project topics and put forward, justify and defend one's ideas; to familiarize with the ways of working with information; to develop self-organization skills (planning activities, programming actions, correcting stages and modes of activity; flexibility and variability of actions); the developmental aspect: to develop one's research and creative skills; to enhance the capacity for self-determination and goal-setting; to develop critical thinking (motivation towards planning, flexible thinking, readiness to correct one's mistakes); to develop analytical skills and reflection (establishing causal relationships, identifying the essential characteristics with an orientation towards the set goal, modeling a particular product); to develop the ability to determine one's position, plan work and time; to develop communication skills; to develop the ability to present one's results; the character-building aspect: to cultivate a sense of responsibility, self-discipline and selforganization; to cultivate motivation towards efficient professional performance; the socializing aspect: to cultivate awareness of the importance of joint efforts in team work; to apply subjective experience of students and coordinate it with scientific content of the project; to motivate towards self-evaluation of pedagogical activity; to shape and develop capabilities and nurture creativity in others. 
Expected outcomes: enhanced readiness of future lecturers in professional education (015 occupational safety and health) for professional self-development and self-improvement; students' comprehension of the chosen profession, the vision of oneself in the chosen profession.

Topical issues: the ways to achieve professionalism of future lecturers in professional education (015 occupational safety and health); self-study activities of future lecturers in professional education (015 occupational safety and health); self-improvement of future lecturers in professional education (015 occupational safety and health); self-design as an effective means of professional self-development of future lecturers in professional education (015 occupational safety and health).

Recommended forms of presenting and defending projects: seminar-workshop.

The organization of project-based activities should involve the following: outlining a specific problem, whose solving requires students to have relevant knowledge and research skills, to be able to critically analyze and discover the necessary information; theoretical, practical and cognitive significance of expected results (e.g., presenting findings at a scientific and practical conference; publishing findings in a scientific journal); independent work of students (individual, pair, group work); structuring the project content and specifying the results of each stage; using the system of research methods, which should include determining research object, research subject, research objectives; outlining research hypothesis; selecting research methods; collecting, systematizing and analyzing information; discussing the obtained results (presentations, publications, web-pages, etc.); formulating conclusions; presenting results; evaluating the project; determining prospects of further research.

The process of implementing the project method in the course on pedagogy of higher education consisted of certain stages: selecting a topic and type of the project, determining the number of participants; analyzing the problems, which are expected to be solved within the framework of the selected topic (problematic issues; situations contributing to solving the problem); distributing tasks among groups, discussing probable research methods, 
searching for relevant information and creative solutions; organizing individual work of project participants according to their individual, group, research and creative tasks; organizing additional discussions of the obtained results in groups; organizing defence of projects, discussions with opponents, expert evaluation, external review; formulating conclusions.

Therefore, the course on pedagogy of higher education should provide future lecturers in professional education (015 occupational safety and health) with the following knowledge: theoretical principles of project-based activities; the procedure of project-based activities organization; the classification of projects; the structure and stages of project implementation; the criteria for evaluating projects; abilities: the ability to select a project topic; to single out problems; to select project sub-topics; to organize creative groups; to prepare an individual plan of work; to determine forms of presenting findings; to coordinate the actions of project participants; to conduct expert evaluation of projects. In addition, the use of the project method in professional training of students, namely in the context of the course on pedagogy of higher education, makes it possible to teach students how to apply the new knowledge in practice to deal with life and professional problems.

\section{Conclusions and prospects of further research in this area.} The need to develop project skills and project thinking in students and motivate them to engage in project-based activities is related to the fact that one should be able to discover new knowledge in the growing flow of information. Nowadays, knowledge is a priority and designing a project can rather extend it.

The use of the project method in professional training of Master professional education (015 occupational safety and health) students in comparison with traditional methods has a number of advantages: the learning process is adjusted to practice; students have the opportunity to engage in independent professional activity; students are faced with the need to find and make optimal decisions; students have the opportunity to creatively acquire the necessary information.

The systemic use of the project method in professional training of students, namely in the context of the course on pedagogy of higher education, contributes to developing 
professional skills and thinking, creative and research skills, problem-solving skills, innovation skills and widening social mindset of future lecturers in professional education (015 occupational safety and health).

Further research should be aimed at analyzing the use of case studies in the course on pedagogy of higher education during professional training of future lecturers in professional education (015 occupational safety and health).

\section{ДЖЕРЕЛА ТА ЛІТЕРАТУРА}

1. Бондар В. І. Дидактика: ефективні технології навчання студентів. К. : Вересень, 1996. 129 с.

2. Гузеев В. В. «Метод проектов» как технология четвёртого поколения // Планирование результатов образования и образовательная технология. М. : Народное образование, 2001. С. 194-207. (Серия «Системные основания образовательной технологии»).

3. Гуревич Р. С. Інформаційні технології навчання : інноваційний підхід : навч. посіб. Вінниця : ТОВ фірма «Планер», 2012. 348 с.

4. Дьюи Дж. Школа будущего. Берлин, 1992. 212 с.

5. Єрмаков I. Г. Метод проектів : традиції, перспективи, життєві результати : практико-зорієнт. зб. К. : Департамент, 2003. С. $15-29$.

6. Зазуліна Л. В. Педагогічні проекти : наук.-метод. посіб. Хмельницький - Кам'янець-Подільський : Абетка-НОВА, 2006. $40 \mathrm{c}$.

7. Килпатрик У. Х. Метод проектов. Применение целевой установки в педагогическом процессе. Л. : Блокгауз-Ефрон, 1925. $43 \mathrm{c}$.

8. Колодницька О. Д. Метод проектів як умова розвитку особистості майбутнього педагога в процесі професійної підготовки у вищих навчальних закладах // Вісник Черкаського університету. Серія : Педагогічні науки. Черкаси, 2009. Вип. 149. С. 63-67.

9. Ліготський О. А. Методичні аспекти проектування сучасних освітніх систем. К. : Преса України, 1995. 107 с. 
10. Логвин В. Метод проектів у контексті сучасної освіти // Сучасні шкільні технології. К. : Ред. загальнопед. газ., 2004. Ч. 2. С. 31-38.

11. Ничкало Н. Педагогічна інноватика у профтехосвіті // Проф.- пед. освіта : спецвип. 2007. № 3. С. 64 - 70.

12. Освітні технології : навч.-метод. посіб. // за ред. О. М. Пєхоти. К. : А.С.К., 2004. 256 с.

13. Пєхота О. Підготовка майбутнього вчителя до впровадження сучасних педагогічних технологій // Неперервна пед. освіта : теорія і практика. 2002. № 2. С. 97 - 106.

14. Пилюгина С. А. Метод проектной деятельности в Интернете и его развивающие возможности // Школьные технологии. 2002. № 2. С. 196-199.

15. Полат Е. С. Метод проектов на уроках иностранного языка // Иностранные языки в школе. 2000. № 3. С. 3-9.

16. Селевко Г. К. Энциклопедия образовательных технологий : в 2 т. М.: НИИ образовательных технологий, 2006. T. 1. 2006. $816 \mathrm{c}$.

17. Ящук С. М. Розвиток творчого потенціалу учнів у процесі проектно-технологічної діяльності // Рідна школа. 2004. № 4. C. 9-11.

18. Robert T.y Education // Journal of Industrial Teacher Education. 2003. Vol. 40, N 3. P. 13.

\section{REFERENCES}

1. Bondar, V. I. (1996). Dydaktyka: efektyvni tekhnolohii navchannia studentiv [Didactic: effective technologies of teaching students]. Kyiv: Veresen [in Ukrainian].

2. Guzeev, V. V. (2001). Planirovanie rezultatov obrazovaniia $i$ obrazovatelnaia tekhnologiia [Planning of learning outcomes and educational technology]. Moscow: Narodnoe obrazovanie [in Russian].

3. Hurevych, R. S. (2012). Informatsiini tekhnolohii navchannia: innovatsiinyi pidkhid [Informational technologies of learning: an innovative approach]. Vinnytsia: Planer [in Ukrainian].

4. Dewey, J. (1992). Shkola budushchego [The school of the future]. Berlin: Gosizdat [in Russian]. 
5. Yermakov, I. H. (2003). Metod proektiv: tradytsii, perspektyvy, zhyttievi rezultaty [The project method: traditions, prospects, life results]. Kyiv: Departament [in Ukrainian].

6. Zazulina, L. V. (2006). Pedahohichni proekty [Pedagogical projects]. Khmelnytskyi- Kamianets-Podilskyi: Abetka-NOVA [in Ukrainian].

7. Kilpatrick, W. (1925). Metod proektov. Primenenie tselevoi ustanovki v pedagogicheskom protsesse [The project method. The use of goals in the pedagogical process]. Leningrad: BlokgauzEfron [in Russian].

8. Kolodnitska, O. D. (2009). Metod proektiv yak umova rozvytku osobystosti maibutnoho pedahoha $\mathrm{v}$ protsesi profesiinoi pidhotovky u vyshchykh navchalnykh zakladakh [The project method as a condition for developing personality in future teacher during professional training in higher education institutions]. Visnyk Cherkaskoho universytetu. Seriia: Pedahohichni nauky. 149. 63-67 [in Ukrainian].

9. Lihotskyi, O. A. (1995). Metodychni aspekty proektuvannia suchasnykh osvitnikh system [Methodical aspects of designing modern education systems]. Kyiv: The Media of Ukraine [in Ukrainian].

10. Lohvyn, V. (2004). Metod proektiv u konteksti suchasnoi osvity [The project method in the context of modern education]. Suchasni shkilni tekhnolohii. 2. 31-38 [in Ukrainian].

11. Nychkalo, N. (2007). Pedahohichna innovatyka u proftekhosviti [Pedagogical innovation in vocational education]. Profesiino-pedahohichna osvita. 3. 64-70 [in Ukrainian].

12. Piekhota, O. (2004). Osvitni tekhnolohii [Educational technologies]. Kyiv: A.S.K. [in Ukrainian].

13. Piekhota, O. (2002). Pidhotovka maibutnoho vchytelia do vprovadzhennia suchasnykh pedahohichnykh tekhnolohii [Preparing future teacher for the implementation of modern pedagogical technologies]. Neperervna pedahohichna osvita: teoriia i praktyka. 2. 97-106 [in Ukrainian].

14. Pilyugina, S. A. (2002). Metod proektnoi deiatelnosti v Internete $i$ ego razvivaiushchie vozmozhnosti [The method of project-based activities on the Internet and its developmental opportunities]. Shkolnye tekhnologii. 2, 196-199 [in Russian]. 
15. Polat, E. S. (2003). Metod proektov: tipologiia i struktura [The project method: typology and structure]. Litseiskoe $i$ gimnazicheskoe obrazovanie. 9.9-17 [in Russian].

16. Selevko, G. K. (2006). Entsiklopediia obrazovatelnykh tekhnologii [Encyclopedia of educational technologies] (Vol. 1-2). Moscow: Scientific Research Institute for Educational Technologies [in Russian].

17. Yashchuk, S. M. (2004). Rozvytok tvorchoho potentsialu uchniv u protsesi proektno-tekhnolohichnoi diialnosti [Developing creative potential in pupils during project-based and technological activities]. Ridna shkola. 4. 9-11 [in Ukrainian].

18. Howell, R. T. (2003). The importance of the project method in technology education. Journal of Industrial Teacher Education. 40 (3). Retrieved from https://scholar.lib.vt.edu/ ejournals/ JITE/v40n3/howell.html [in English].

\section{АНОТАЦІЯ}

У статті на основі аналізу наукової літератури з'ясовано специфіку використання методу проектів у процесі професійної підготовки майбутніх викладачів професійної освіти (охорона праці) під час вивчення дисципліни «Педагогіка вищуої иколи».

Наведені різні підходи до визначення сутності методу проектів, який науковці розглядають як: метод, вид навчання, діяльність, технологія навчання. На основі врахування різних поглядів науковців щцодо трактування поняття метод проектів (проектна технологія), ми розглядаємо як сукупність навчально-пізнавальних прийомів, які дозволяють студентам набути нових знань, вмінь та навичок в прочесі самостійной діяльності, щуо орієнтована на творчу самореалізацію особистості в освітньому прочесі та спрямована на підвищення їхньої професійної підготовки в закладі вищої освіти.

У статті проаналізовано та розкрито сутність, зміст та структуру методу проектів. Доведено, що використання методу проектів у професійній підготовиі магістрантів зі спеціальності 015 Професійна освіта (охорона прачі) порівняно з традиційними методами має низку переваг, а саме: 
в процесі проектної діяльності студенти інтегрують свої знання з різних навчальних дисциплін; набувають навичок самоосвіти иляхом засвоєння необхідної інформачї, аналізуючи та узагальнюючи їі; студенти накопичують досвід в самостійній професійній діяльності під час вирішення проблемних завдань.

У статті доведено, щуо систематичне використання методу проектів в практиці роботи вищуої школи, зокрема під час вивчення дисчииліни «Педагогіка вищзої иколи» у процесі професійної підготовки майбутніх викладачів професійної освіти (охорона праці) сприяє виробленню вмінь $і$ навичок проектування майбутньої діяльності, формує здатність самостійно вирішувати професійні проблеми, застосовуючи знання з різних галузей, розвиває професійне мислення, дослідницькі та творчі здібності, формує компетениіі (пізнавальні, комунікативні, дослідницькі, проектувальні та ін.), формуває здатність та готовність до інноваційної професійної діяльності.

Ключові слова: вищуа школа, метод проектів, проектна діяльність, компетентність, професійна підготовка, майбутні викладачі професійнӧ освіти (охорона прачі), дисиипліна «Педагогіка вищої иколи», освітній процес.

\section{АННОТАЦИЯ}

В cтатье на основе анализа научной литературы определена специфика использования метода проектов в процессе профессиональной подготовки будущчих преподавателей профессионального образования (охрана труда) во время изучения дисциплины «Педагогика высшей школь»».

Приведенные разные подходы к определению сущуности метода проектов, который ученые рассматривают как: метод, вид учебы, деятельность, технология учебы. На основе учитыввания разных взглядов ученых относительно опредиления понятия метод проектов (проектная технология), мы его рассматриваем как совокупность учебнопознавательных приемов, которые позволяют студентам приобрести новые знания, умения и навыки в процессе 
самостоятельной деятельности, которая ориентирована на творческую самореализацию личности в образовательном прочессе и направлена на повышение их профессиональной подготовки в заведении высшего образования.

В статье проанализирована и раскрыта сущиость, содержание и структура метода проектов. Доказано, что использование метода проектов в профессиональной подготовке магистрантов из специальности 015 Профессиональное образование (охрана труда) сравнительно с традиционными методами имеет ряд преимуществ, а именно: в процессе проектной деятельности студенть интегрируют свои знания из разных учебных дисциплин; приобретают навыки самообразования путем усвоения необходимой информации, анализируя и обобщая ее; студенть накапливают опыт в самостоятельной профессиональной деятельности во время решения проблемных заданий.

В статье доказано, что систематическое использование метода проектов в практике работы высшей школь, в частности во время изучения дисциплины «Педагогика высшей школь»» в прочессе профессиональной подготовки будущчих преподавателей профессионального образования (охрана труда) способствует выработке умений и навыков проектирования будущцей деятельности, формирует способность самостоятельно разрешать профессиональные проблемь, применяя знание из разных отраслей, развивает профессиональное мышление, исследовательские и творческие способности, формирует компетенции (познавательные, коммуникативные, исследовательские, проектировочные и др.), формуває способность и готовность к инновационной профессиональной деятельности.

Ключевые слова: высшая школа, метод проектов, проектная деятельность, компетентность, профессиональная подготовка, будущие преподаватели профессионального образования (охрана труда), дисииплина «Педагогика высшей школь»», образовательный процесс.

Надійшла до редакиії: 11.01.2019 p. Прийнята до друку: 29.01.2019 p. 